\title{
MEMAKNAI HAK DAN KEWAJIBAN DALAM \\ KEBIJAKANKERJASAMA SWASTA DENGAN PEMERINTAH \\ DAERAH(PEMDA) MELALUI PERJANJIAN BUILD OPERATE TRANSFER (BOT) BIDANG PASAR
}

\author{
Muhammad Dzikirullah H Noho \\ Program Studi Hukum Ekonomi Syariah, Universitas Hasyim Asy’ari, Jombang, \\ Indonesia \\ Email: mdzikirullah@gmail.com
}

\begin{abstract}
Abstrak
Hak dan kewajiban dalam perjanjian kerjasama Pemerintah Daerah dengan Swasta dapat dilihat dari keseimbangan berkontrak, keseimbangan sendiri merupakan prinsip yang harus dipatuhi oleh para pihak dalam menjalankan perjanjian. Keseimbangan ini penting untuk membangun kesetaraan bagi para pihak yang berkontrak terkait dengan hak dan kewajiban. Namun, memaknai kesetaraan ini yang masih sulit. Kedua belah pihak memiliki kepentingan masing-masing. Metode yang digunakan dalam penelitian ini adalah metode kualitatif melalui pendekatan interpretatif, di mana melalui pendekatan ini adanya penekanan untuk melihat relasi teks satu dengan teks yang lain. Bertolak dari pendekatan tersebut maka untuk menggambarkan teks dalam kebijakan kerjasama swasta dengan (Pemda) dalam Perjanjian BOT dapat dilakukan dengan menggunakan the signifiying order dan analisa tiga dimensi yang dicetuskan oleh Danesi dan Perron. Pemahaman hak dan kewajiban kontrak BOT dilihat sebagai realitas baik itu sosial maupun hukum. Realitas ini sebagai landasan penyeimbang beroperasi sebuah perjanjian kerjasama swasta. Melaui relasi antara teks sebagai hak dan teks sebagai suatu kewajiban akan tergambarkan jika peran-peran para pihak di dalam kerjasama swasta dengan pemerintah daerah saling mengetahui tugas dan fungsinya masing-masing.
\end{abstract}

Kata kunci : Kerja sama daerah, kontrak BOT, pendekatan interpretatif

\begin{abstract}
Rights and obligations in the Regional Government cooperation agreement with Swata can be seen from the balance of contract, the balance itself is the principle that requires both parties to fulfill and implement the agreement. This balance is important to build equality for the parties involved in relation to rights and obligations. However, interpreting this equality is still difficult. Both parties have their own interests. This study uses a qualitative method with an interpretive approach, where through this approach there is an emphasis to see one text relation with another text. Based on this approach, to illustrate the text in the policy of between cooperation regional government and the sector private in BOT contact, it can be done using the signifiying order and threedimensional analysis triggered by Danesi and Perron. Understanding the rights and obligations of BOT contracts is seen as a reality both social and legal. This reality as a balancing ground operates a private cooperation agreement. Through the relationship between text as rights and texts as an obligation, it will be illustrated if the roles of the parties in private cooperation with the local government are mutually aware of their respective duties and functions.
\end{abstract}

Keywords: Regional cooperation, BOT contracts, interpretative approach

Submited: 13-02-2019; Accepted: 30-04-2019; Published: 30-04-2019

*Korespondensi: Program Studi Hukum Ekonomi Syariah, Universitas Hasyim Asy'ari,

Jl. Irian Jaya No. 55, Cukir, Diwek, Jombang, Jawa Timur 61471

Email: mdzikirullah@gmail.com 


\section{2 | The Journal of Society and Media 3(1)}

\section{PENDAHULUAN}

Sarana dan prasarana infrastruktur dalam pembangunan merupakan kewajiban pemerintah. Salah satunya adalah kebutuhan untuk melayani mayarakat pada era globalisasi. Dengan keterbatasan anggaran membuat pemerintah harus melibatkan pihak swasta dalam rangka membangun dan mengoperasikan sarana dan prasarana untuk memenuhi kebutuhan masyarakat secara luas. Dalam mewujudkan pembangunan sarana dan prasarana infrastruktur dan pelayanan publik tidak lain bertujun untuk mensejahterakan masyarakat. Munculnya konsep Publik Private Partnership (PPP), ini merupakan skema kerjasama yang dibuat dalam perjanjian dan melibatkan pihak pemerintah dengan pihak swasta untuk melayani dan memenuhi kebutuhan masyarakat (Abbas n.d.).

Sebutan lain dari PPP adalah Kerjasama Pemerintah Swasta (KPS), hal ini merupakan skema pembiayaan alternatif yang digunakan dibeberapa negara khususnya negara maju dalam rangka pengadaan pelayanan publik bidang infrastruktur. Hadirnya swasta di bidang pelayanan infrastruktur yang diadakan oleh pemrintah akibatnya muncul berbagai jenis perjanjian antara pihak swasta dengan pemerintah. Kehadiran tersebut juga merupakan harapan besar bagi pembangunan sebuah negara dalam kaitannya dengan investasi serta peningkatan pelayanan infrastruktur kedepannya. Namun tidak dapat dipungkiri hal tersebut juga mempunyai problematika yang cukup kompleks sebab banyaknya kepentingan dari para pihak yakni swasta dan pemerintah. Satu sisi pemerintah berkeinginan memberikan pelayanan infrastruktur yang terbaik bagi masyarakat sedangkan sisi lain pihak swasta berkeinginan mengeruk keuntungan sebesarbesarnya (Masitoh 2014a).

Dengan hadirnya swasta sebagai mitra pemerintah dalam membangun infrastuktur yang berbasis pada pelayanan masyarakat mengakibatkan muncul berbagai model perjanjian kerjasama antara swasta dengan pemerintah, maka tidak bisa dipungkiri jika mulai bermunculan model-model perjanjian kerjsama swasta dengan pemerintah, contohnya seperti Build operate Transfer (BOT), Build Own Operate (BOO), Build Rent Operate Transfer (BROT), Kerjasama operasi/Joint Operation (KSO), patungan usaha, ruislag dan sebagainya. Hal ini merupaakan terobosan bagi kerjasama swasta dengan pemerintah (Masitoh 2014b). 


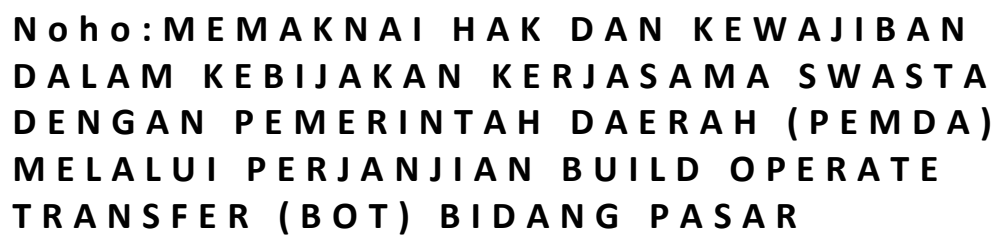

Berbagai skema kerjasama pemerintah dengan swasta diatas yang seringkali digunakan oleh pemerintah daerah adalah skema BOT. Build, Operate and Transfer/BOT (Bangun Guna Serah), di mana merupakan salah satu jenis perjanjian yang pelaksanaannya dilakukan oleh pemilik lahan (pemerintah) dengan pengelola lahan (investor). Pengelola lahan berhak membangun dan mengelola dalam jangka waktu perjanjian Build, Operate andTransfer/BOT (Bangun Guna Serah) dan menyerahkan hak guna banguna dan/atau hak pakai kepada pemilik lahan bilamana jangka waktu yang diperjanjian dalam build operate transfer habis (Justisia 2015).

Perjanjian merupakan tindakan hukum berlandaskan kata sepakat yang mempunyai akibat hukum. Pengertian tersebut serupa dengan yang disampaikan oleh Sudikno Mertokusumo, "perjanjian merupakan hubungan hukum antara dua pihak atau lebih berdasar kata sepakat untuk menimbulkan suatu akibat hukum" (Prasetyo 2017). Khusunya "kontrak" secara harfiah berasal dari inggris yaitu contract, adalah: "dua atau lebih orang dalam membuat kesepakatan di antara mereka dan menimbulkan kewajiban untuk melaksanakan sesuatu atau tidak melaksanakan sesuatu.

Di dalam Buku III KUHPer secara eksplisit menjelasakan mengenai kontrak, mengatur terkait dengan perikatan yang lahir dari perjanjin dan perikatan yang lahir dari undang-undang seperti halnya perbuatan melawan hukum (PMH). KUHPer juga mengatur terkait dengan aturan main yang bersifat umum yang berlaku bagi semua perjanjian atau disebut perjanjian nominat dan terdapat juga aturan main yang bersifat khusus atau disebut innominat yang sudah tertera dalam undang-undang (Prasetyo 2017).

Perumusan Pasal 1313 KUHPer mengartikan "perjanjian" adalah "Suatu perjanjian adalah suatu perbuatan di mana satu orang atau lebih mengikatkan diri terhadap satu orang lain atau lebih" bilama dirumuskan perjanjian secara tertulis yang meimbulkan bukti adanya kewajiban diantara mereka (secara tidak langsung terdapat hak) yang bersifat mengikat, dapat dikatakan sebuah kontrak. Menurut Cicero tentang De Legibus : "Quae scripto sancit quod vult, aut iubendo, aut vetando" (suatu hal yang tertulis, dapat disetujui secara baik atau tidak disetujui). 
Secara umum apa yang dikatakan oleh Cicero itu mempunyai dampak bahwa suatu perjanjian yang tidak terulis tidak perlu dianggap sebai suatu hal yang disetujui atau tidak disetujui (Kusumohamidjojo 2015).

Pada perjanjian atau kontrak, hak dan kewajiban biasanya dilihat dari keseimbangan berkontrak, keseimbangan sendiri merupakan asas yang menghendaki kedua belah pihak memenuhi dan melaksanakan perjanjian. Kreditur mempunyai kekuatan untuk menuntut prestasi dan jika diperlukan dapat menuntut pelunasan prestasi melalui kekayaan debitur, namun debitur memikul pula kewajiban untuk melaksanakan perjanjian itu dengan itikad baik.

Keseimbangan ini penting untuk membangun kesetaraan bagi para pihak yang berkontrak terkait dengan hak dan kewajiban. Adanya keseimbangan menuntut agar kesepakatan yang dibuat oleh para pihak dapat dipenuhi dan dilaksanakan sesuai dengan isi perjanjian. Salah satu pihak mempunyai kewajiban menuntut isi perjanjian serta dapat menuntut pelunasan terkait dengan perjanjian, namun yang menjadi beban adalah pelaksanaan itikad baik dalam menjalankan perjanjian. Oleh karena itu sebuah perjanjian akan menjadi kuat atau lemah terkandung kecermatan dalam memperhatikan peran itikad dalam mencapai keseimbangan berkontrak(Mulyati 2016).

Namun, memaknai kesetaraan ini yang masih Sulit. Kedua belah pihak memiliki kepentingan masing-masing. Misalnya dalam kontrak build operate transfer (BOT) bidang pasar. Para pihak mempunyai posisi tawar yang sama, pihak pemerintah (pemilik lahan) memberikan kewenangan kepada pengusaha (pengelola lahan) untuk mengembangkan sarana dan prasaran infrasturktur dan kemudian melaksanakanya dalam waktu yang ditentukan atau biasa disebut konsesi sedangkan pihak pengusaha (pengelola lahan) membangun dengan costnya sendiri, mengelola, dan mengembalikan kepada pemlik lahan dalam keadaan utuh bila jangka waktu yang ditentukan telah habis. Keduanya digambarkan saling membutuhkan, pemerintah mengingkan dana untuk pembangunan pasar dan pengusaha membutuhkan lahan untuk mengeruk keuntungan.

Meskipun adanya hubungan simbiosis mutualisme dalam mencapai keuntungan yang sama, akan tetapi penuangan dalam kontrak BOT bidang pasar masih terlihat adanya dominasi baik itu haknya maupun kewajibannya. Berdasarkan latar belakang di atas maka perlu lebih lanjut membahas bagaiamana bentuk hak dan kewajiban swasta dengan pemerintah di dalam perjanjian BOT 


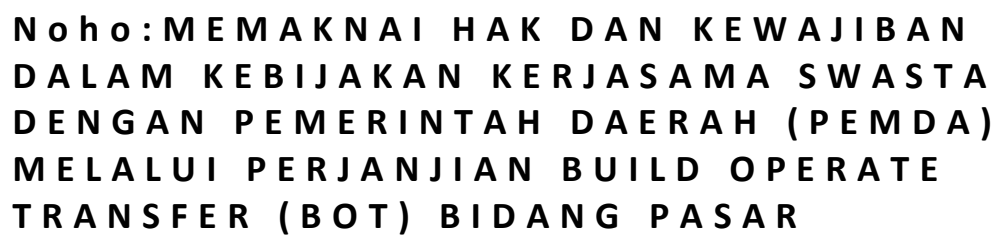

dan bagaimana memaknai hak dan kewajiban tersebut dalam mewujudukan pemahaman dan menghindari dominasi dalam berkontrak. Oleh karenanya perlu untuk diangkat judul tentang memaknai hak dan kewajiban dalam kebijakan kerjasama swasta dengan pemerintah daerah (Pemda) melalui perjanjian build operate transfer (BOT) bidang pasar.

\section{METODE PENELITIAN}

Pendekatan dalam makalah ini menggunakan kualitatif, khusunya pendekatan interpretatif. Pendekatan ini merupakan pendekatan yang menekankan pada pehaman terkait dengan apa yang muncul dibalik tingkah laku manusia sebagai fenomena sosial yang ada (Thohir 2007a). Menggunakan fondasi berfikir yang menempatkan fenomena sosial bukan sebagai bentuk yang utuh akan tetapi melihat makna yang melatarbelakangi tindakan seseorang yang membentuk pola. Kaitannya dengan pemaknaan harus memperhatikan beberapa hal yang meliputi pertama, tindakan manusia akan sesuai dengan apa yang dimaknai dari realitas baik itu bewujud atau tidak berwujud. Kedua, munculnya makna dari dalam hubungan sesama masyarakat, dan ketiga, makna apa yang ditafsirkan oleh manusia dalam memandang realitas yang ada disekelilingnya. Maka dari itu, penelitian sosbud (sosial dan budaya) memfokuskan pada fenomena relasi antarmanusia dan apa yang terkandung dalam makna dibalik relasi itu. Makna disini berkaitan dengan semua ide, kepercayaan, nilai , kenginginan, maksud dan motivasi para manusianya (Thohir 2007b).

Bertolak dari pendekatan metode di atas maka teori yang mendukung analisa dalam penelitian yaitu dengan menggunakan teori the signifying order dan analisa tiga dimensi yang dipaparkan oleh Danesi dan Perron. Di mana tanda sebagai gejala sosial digambarkannya sebagai "the signifying order" (sistem pemaknaan yang terbagi secara sosial saat seseorang menjadi dewasa dan memasuki kehidupan masyarakat). Sedangkan analisa tiga dimensi merupakan salah satu metode untuk menggambarkan pemaknaan tanda dari tiga sudut pandang yaitu paradigmatik, sintagmatik, dan analogi (Abdullah 2017a). 


\section{HASIL DAN PEMBAHASAN}

\section{Bentuk Hak Dan Kewajiban Dalam Kebijakan Kerjasama Swasta dengan Pemda Dalam Kontrak BOT Bidang Pasar}

Di Indonesia pengaturan build operate transfer/bangun guna serah (BOT) mulanya diatur melalui kementrian keuangan dengan Keputusan Menteri Keuangan No. 248/KMK.04/1995 terkait Perlakuan Pajak Penghasilan terhadap Pihak-pihak yang Melakukan Kerjasama dalam Bentuk Perjanjian Bangun Guna Serah (Build Operate and Transfer). Pengaturan yang dibuat oleh Kementrian Keuangan tersebut secara tegas hanya meliputi lingkup perpajakan sedangkan mekanisme perjanjian BOT tidak dijelaskan di dalamnya. Kemudian muncul peraturan lainnya pada tahun 2001, Kementrian Dalam Negeri dan Otonomi Daerah atau sekarang disebut Kementrian Dalam Negeri mengeluarkan Keputusan Menteri Dalam Negeri dan Otonomi Daerah No. 11 Tahun 2001 tentang Pedoman Pengelolaan Barang Daerah dan di tahun 2016 muncul perubahan menjadi Permendagri No. 19 Tahun 2016 tentang Pengelolaa barang milik daerah, namun penjelasan aturan tersebut tidak spesifik mengatur mengenai build operate transfer.

Khususnya pengaturan kerjasama swasta dengan pemerintah dengan skema BOT bidang pasar selama ini para pihak dalam membuat perjanjian berlandaskan pada UU No. 18 Tahun 1999 Tentang Jasa Konstruksi, PP No 6 Tahun 2006 tentang pengelolaan barang milik Negara/Daerah sebagaiamana perubahan dengan munculnya PP No. 38 Tahun 2008, Permendagri Tahun 2007 Tentang pedoman teknis pengelolan barang milik daerah, dan Permekeu No. 96 Tahun 2007 tentang tata cara pelasksanaan penggunaan, pemanfaatan, penghapusan, dan pemindahtanganan barang milik negara.

Gagasan yang adal di dalam BOT menjelaskan adanya kategorisasi ruang lingkup infrastuktur sebagai berikut (Santoso 2008):

" To have any projects which really belonged to the public sector implemented by the private organization without the state, the province, the city or the commune providing any guarante or accepting any liability. The project which were intended to be self financing". 


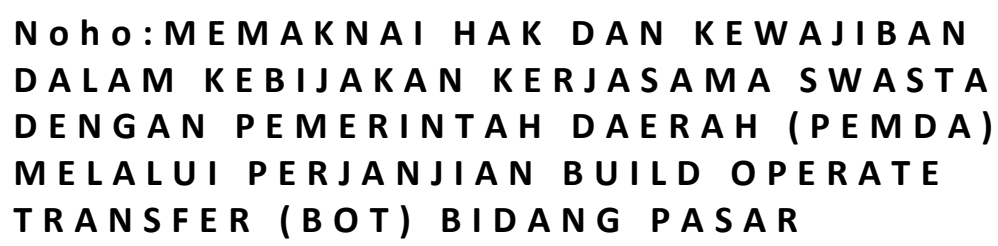

Pengertian Build and transfer adalah skema pendanaan yang digunakan untuk mengembangkan sector private atau biasa disebut dengan skema pembangunan dan pengelolaan infrastruktur. Singar Durba membuat sebuah makalah dalam acara National Planing CommisionNepal, di dalam acara dia sampaikan bahwa (Durbar 2000):

"Any one of the following systems (hereafter called Infrastructure Developmentsystem) can be adopted in the process ofinfrastructure development from the privatesector :Build, operate and transfer;Build own and operate;Build own, operateand transfer ;Build, own, operate and sell;Build ,Transfer and operate; Lease in developand operate ;Rehabilitate, operate and Transfers."

Perjanjian BOT, merupakan perjanjian yang melibatkan pemerintah dengan investor dengan memberikan kemanfaatan bagi pihak ketiga yakni masyarakat. Keberadaan perjanjian BOT ini masuk dalam dua ranah hukum yang bersifat privat dan publik maka kepentingan masyarakat sebagai variabel di dalamnya menjadi sangat penting untuk dicermati. Para pihak yang disebutkan oleh perjanjian BOT harus mengedapnkan prinsip tanggungjawab sebab pertanggungjawaban perjanjian ini berlandaskan pada unsur kesalahan. Unsur kesalahan disini tidak memihak kepada salah satu pihak, bagi pihak manapun yang secara unsur memenuhi Pasal 1365 KUHPer yang menyebutkan bahwa “tiap perbuatan melanggar hukum, yang membawa kerugian kepada seorang lain, mewajibkan orang yang karena salahnya menerbitkan kerugian itu mengganti kerugian tersebut, dapat digugat". Dalam persoalan lain bagi pemerintah maupun swasta dapat menggugat apabila terdapat adanya perbuatan melanggar hukum, menimbulkan kerugian serta mempuyai hubungan sebab akibat antara kerugian dengan perbuatan melanggar hukum (Setlight 2011).

Secara umum perjanjian yang dibuat dengan menggukan skema BOT akan melibatkan beberapa pihak diantaranya pemilik lahan adalah pemerintah sedangkan pengelolan lahan adalah swasta. Pemilik lahan mendistribusikan kewenangannya sementara kepada pengelola lahan dalam jangka waktu yang ditentukan dan pengelola lahan harus mengembalikan objek yang diperjanjikan 
kepada pemlik lahan apabila jangka waktu yang diperjanjikan telah habis(Adha 2011). Ada pun tugas dan fungsi pemilik lahan dan pengelola lahan dalam perjanjian dengan skema BOT bidang Pasar (Smith 1999):

a. Pemilik lahan: Selaku pihak yang menyerahkan konsesi, pada umumnya adalah Pemerintah pusat atau pemerintah daerah atau otoritas pemerinah. Peran pemerintah seringkali mengemban tugas sebagai pihak yang mempunyai otoritas atas pemberian konsesi.

b. Funding atau lembaga pembiayaan: lembaga pembiayan disini seringkali berkaitan perusahan-yang bergerak di bidang keuangan dan asuransi baik itu perbankan ataupun asuransi. Hal terpenting dari adanya lembaga keuangan akan adalah sebagai salah satu cara mengukur neraca keuangan tahunan pengelola lahan, bukti pembiayaan, sekaligus dengan barang-barang yang diagunkan.

c. Pengelola lahan: Pengelola lahan ini menjadi syarat dalam skema BOT. Pengelola lahan dapat dilakukan oleh perusahan atau konsorsium beberapa perusahan dengan tujuan mengelola lahan, mencari keuntungan, dan menyerahkan kembali kepada Pemerintah apabila jangka waktu perjanjiannya telah habis. Di dalam konsorsium terdapat beberapa perusahan yang bergerak di bidang komersil, biasanya perusahan ini melebur menjadi satu dengan menggunakn kerjasama operasi (KSO). Melalui kerjasama KSO perusahan akan lebih mudah membagi tugas dan fungsi dari tiap mitra perusahan. Di masa lalu model konsorsium ini dilakukan oleh berbagai perusahan yang bergerak di bidang hukum, keuangan, dan teknik baik itu sipil atau arsitektur, hal ini dilakukan agar lahan yang dikelola dapat berjalan dengan baik dan mengeruk keuntungan yang banyak.

Diantara tiga pihak utama diatas yang seringkali muncul dalam kontrak BOT bidang pasar hanyalah pemilik lahan dan pengelola lahan. Dalam menjalankan fungsi-fungsi mereka maka di buatlah hak dan kewajiban untuk mengatur batasan-batasan serta kewenangan para pihak dalam bertindak. Model kontrak BOT sepert di atas juga dilakukan di Kota Malang yang dilakukan oleh Pemda Kota Malang dan PT. CGA. Pembiayan dengan model kontrak BOT tersebut dibuat dalam bentuk Perjanjian dan diberi nama pembangunan dan pengelolaan kawasan Pasar Terpadu Dinoyo. Adapun isi dari hak dan kewajiban perjanjian berikut ini (Anon 2011): 


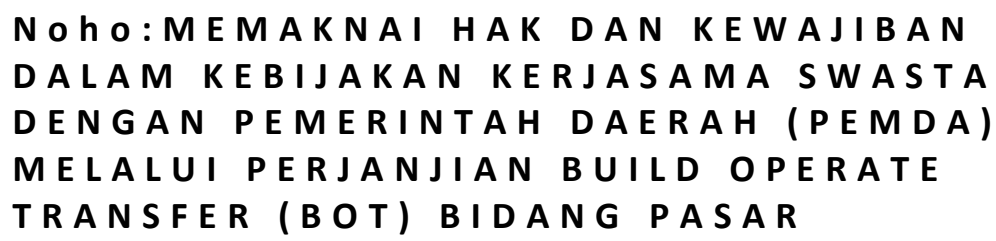

a. Hak dan kewajiban Pemerintah Kota Malang

1) Hak: Menerima objek perjanjian kerjasama beserta segala sesuatu yang tertanam dan berdiri diatasnya berikut sarana penunjangnya dalam keadaan lengkap, baik, layak huni, dan layak pakai sesuai standar teknis yang berlaku, serta bukti hak berupa sertifikat HGB atas nama pihak kedua atau pihak lain yang ditunjuk oleh pihak kedua dalam keadaan bebas sengketa dan tidak adanya pembebanan apapun pada saat perjanjian kerjasama ini berakhir; Mendapatkan kepasatian bahwa pihak kedua menanggung semua biaya dan resiko dalam kegiatan persiapan, pelaksanaan, pemeliharaan, dan penilaian tim independen sampai dengan kembali pada saat berakhirnya perjanjian kerjasama; dan mendapatkan jaminan kepastian dan ketaatan dari pihak kedua dalam merealisasikan isi kesepakatan perdamaian antara pedagang pasar Dinoyo dengan Pemerintah Kota Malang terkait rencana pembangunan Pasar Terpadu Dinoyo Kota Malang tanggal 5 Mei 2010, yang merupakan hasil media komisi nasioanl hak asasi manusia dan telah didaftarkan di kepaniteraan Pengadilan Negeri Malang.

2) Kewajiban: Menyerahkan kepada pihak kedua lahan pasar Dinoyo atas objek perjanjian kerjasama paling lambat 1 (satu) bulan setelah selesainya pembangunan Pasar Tempat Penampungan sementara dan sudah tidak ada lagi Pedagang Pasar Dinoyo beserta barangnya yang berada di objek perjanjian kerjasama; memberikan bantuan dan kemudahan kepada pihak kedua dalam memperolej ijin-ijin dari instansi yang berwenang pada objek perjanjian kerajasama ini sesuai dengan ketentuan perundang-undangan; Memberikan persetujuan kepada pihak kedua untuk memanfaatkan, mengelola, menyewakan Hak Guna Bangunan (HGB) berikut bangunannya kepada pihak lain pada objek perjanjian kerjasama, paling lambat sampai dengan berakhirnya perjanjian kerjasama ini; dan Mentaati dan melaksanakan isi kesepakatan perdamaian antara pedagang pasar Dinoyo dengan Pemerintah Kota Malang terkait rencana pembangunan Pasar Terpadu Dinoyo Kota Malang tanggal 5 Mei 2010, yang merupakan hasil 
60| The Journal of Society and Media 3(1)

media komisi nasioanl hak asasi manusia dan telah didaftarkan di kepaniteraan Pengadilan Negeri Malang.

b. Hak dan kewajiban PT. Citra Gading Asritama

1) Hak: Mendapatkan bantuan dan kemudahan dalam memperoleh ijin-ijin dari instansi yang berwenang pada objek perjanjian kerajasama ini sesuai dengan ketentuan perundang-undangan; Memanfaatkan, mengelola, menyewakan Hak Guna Bangunan (HGB) berikut bangunannya kepada pihak lain pada objek perjanjian kerjasama, paling lambat sampai dengan berakhirnya perjanjian kerjasama ini;

2) Kewajiban : Menyerahkan kepada pihak kesatu objek perjanjian kerjasama beserta segala sesuatu yang tertanam dan berdiri diatasnya berikut sarana penunjangnya dalam keadaan lengkap, baik, layak huni, dan layak pakai sesuai standar teknis yang berlaku, serta bukti hak berupa sertifikat HGB atas nama pihak kedua atau pihak lain yang ditunjuk oleh pihak kedua dalam keadaan bebas sengketa dan tidak adanya pembebanan apapun pada saat perjanjian kerjasama ini berakhir; Menanggung semua biaya dan resiko dalam kegiatan persiapan, pelaksanaan, pemeliharaan, dan penilaian tim independen sampai dengan kembali pada saat berakhirnya perjanjian kerjasama; dan Mentaati dan melaksanakan isi kesepakatan perdamaian antara pedagang pasar Dinoyo dengan Pemerintah Kota Malang terkait rencana pembangunan Pasar Terpadu Dinoyo Kota Malang tanggal 5 Mei 2010, yang merupakan hasil media komisi nasioanl hak asasi manusia dan telah didaftarkan di kepaniteraan Pengadilan Negeri Malang.

\section{Memaknai Hak dan Kewajiban Swasta dengan Pemda Yang Tertuang Dalam Kontrak BOT}

Melalui kontrak Build Operate Transfer (BOT) bidang pasar pemerintah dapat membangun wilayah kepemimpinannya dan meminimalisir penggunaan anggaran pendapatan belanja daerah (APBD). Paradigma dalam pembangunan ini menyangkut kepada pandangan dan cara kita memahamkan dan menjelaskan mengenai esensi pembangunan, mengapa dipilih dan bagaiamana mewujudkan pilihan itu. Model dari pembangunan adalah implementasi proses-proses pembangunan yang bergerak-dari dan bergerak atas- blue print pembangunan yang tealh disepakati berlakunya (Thohir 2007c). 
Dengan demikian maka pembangunan dilihat dari perspektif sosial budaya adalah proses negosiasi dari sejumlah pihak dalam kerangka kepentingan perubahan yang disengaja guna peningkatan kualitas kehidupan itu sendiri. Sebagai suatu proses negosiasi maka terdapat sifat-sifat yang hampir pasti menyertainya yaitu :"ketegangan" dan "titik temu". Dalam konteks seperti inilah pemberian informasi secara fair, duduk sama rendah-berdiri sama tinggi-dan dibalut dengan perasaan saling belajar menghormati dan dihormati. Sebaliknya jika mengabaikan hal-hal seperti itu, akan mudah memunculkan sika prejudice, dan like-dislike (Thohir 2007d).

Dengan menggunakan pendekatan interpretatif akan berupaya untuk memberikan pemahaman bagi semua pihak. Interpretatif secara etimologi mirip dengan hermeneutika sebagai verb serta noun yang seringkali juga diartikan sebagai menafsirkan maupun ditafsirkan, dapat juga menjadi menginterpretasikan maupun interpretasi. Oleh sebab itu, salah seorang ahli filsafat seperti Chladenius secara implisit menyebut interpretasi untuk merubah istilah Yunani, hermeneutika itu (Abdullah 2017b).

Ricoeur (1976) dalam bukunya Interpretation theory: Discourse and the surplus meaning. Menjelaskan bahwa interpretasi memberikan arahan pemahaman, pertama, pemahaman bahasa yang bermuara pada pemahaman teks, tidak hanya dalam arti pusi, narasi, novel, drama, dan esai, tetapi juga pada tataran, yang memperlakukan gejala sosial sebagai teks. Kedua, tujuan pemahaman tersebut dilakukan dengan mengubah pemikiran dari dikotomi terhadap tanda-tanda di dalam struktur dan sistem bahasa (Thohir 2007e).

Pemahaman yang terpenting yaitu keterbukaan dan partisipasi, bukan pengendalian dan manipulasi. Hadirnya hermeneutik sebagai metode penafsiran, di mana tidak hanya melihat teks secara utuh, namun berusahan menelusuri ada apa dibalik makna teks tersebut. Hermeneutika berusaha mencari arti makna melalui pertimbangan horison - horison (cakrawala) yang ada dalam sebuah teks. Maksud dari horison tersebut yaitu pembaca, horison teks, dan pengarang. Melalui tiga pertimbangan horsion di atas diperlukan adanya sebuah upaya peanfsiran dari rekonstrusi kegiatan atau pemahaman dan mereproduksi pemaknaan teks, serta 
mencari tahu munculnya sebuah teks oleh seorang pengarang dan masuknya muatan di dalamnya serta hadirnya pengarang ke dalam sebuah teks, juga berusaha melahirkan (Lutfi n.d.).

Pada hukum kontrak juga membutuhkan interpretasi. Perjanjian BOT bidang pasar sebagai sebuah teks adalah konstruksi sosial dengan cara negosiasi oleh kedua belah pihak. Francis Lieber menyatakan bahwa melalui hermeneutika dalam ilmu hukum memberikan pemahaman baru dalam memaknai kata, teks atau isi dari hukum itu sendiri. Menurut Lieber, tidak hanya hukum saja yang menggukan hermeneutika akan tetapi hal ini juga bagi berlaku bagi semua ilmu pengetahuan. Lieber menerangkan bahwa:

" Tidak ada alasan bagi istilah (hermeneutika) ini untuk tidak digunakan dalam semua ilmu pengetahuan dimana interpretasi dan konstruksi merupakan hal yang diperlukan; ringkasnya, di semua cabang ilmu dimana kita dituntut untuk memastikan pengertian kata-kata dan mengatur tindakan agar sesuai dengan semangat dan kandungannya"(Urbanus Ura Weruin 2016).

Secara tegas perkataan Lieber yang menjelaskan objek-objek hermeneutika juga mencakup wilayah politik dan hukum. Melalui dua bidang ilmu tersebut seringkali digunakan untuk memanipulasi interpretasi, bahasa, serta membangun makna demi tujuan dan kepentingan kelompok masing-masing. Maka menurut Lieber, hermeneutika tidak hanya sekedar ada dalam politik dan hukum, akan tetapi menjadi bagian terpenting dalam politik dan hukum itu sendiri. Para hakim, pengacara, legislator, para pihak dalam berkontrak, serta administrator memerlukan peraturan yang aman, tepat dan sehat bagi konstruksi interpretasi.

Dalam menafsirkan hukum kontrak, khususnya hak dan kewajiban dalam kontrak BOT bidang pasar menggunakan teorinya Marcel Danesi dan Paul Perron mengenai The Signifiying order dan analisa tiga dimensi. Danesi dan Perron merupakan pakar semiotik yang menempatkan semiotik sebagai alat analisa untuk memahami kebudayaan (Abdullah 2017c). Dalam the signifying order kontrak BOT bidang pasar dianggap merepresentasikan realitas baik itu sosial maupun hukum. Realitas diartikan dalam makna sosial yaitu masyarakat (pedagang) yang berjual di pasar tersebut dan realitas diartikan dalam makna hukum yaitu proses sosial yang bersifat negosiasi yang telah dilewati oleh para pihak dalam membuat aturan main (kontrak) berdirinya pembangunan pasar. 


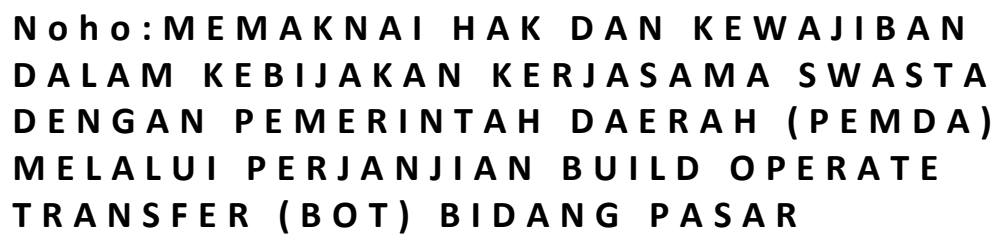

Namun pada realitas tidak seperti itu, karena makna pada realitas mengenai anggapan diatas yang terjadi hukum kontrak BOT dalam bidang pasar sebagai teks bersifat memaksa dan mengatur masyarakat (pedagang) yang ada, bukan sebaliknya masyarakat (pedagang) yang membentuk aturan main hukum kontrak tersebut. Sehingga makna kontrak BOT bidang pasar adanya otonomi dan dominasi realitas hukum yang cukup besar, seolah - olah ada otoritas kuasa kontrak yang menjadi sumber dominan.

Sedangkan melalui metode analisa tiga dimensi akan lebih mudah untuk memahami tanda sebagai gejala budaya. Pengertian intinya adalah bahwa dalam penelitian tentang pemaknaan tanda kita harus melihatnya dalam tiga sudut pandang (dimensi) agar memperoleh pemahaman yang lengkap. Pemahaman tersebut akan digunakan untuk menggambarkan makna-makna yang tertuang di dalam kontrak BOT antara pemerintah daerah dengan swasta. Adapun pemaknaan dari dimensi-dimensi tersebut akan dijelaskan di bawah ini.

Pertama adalah Paradigmatik (Abdullah 2017d), suatu tanda dilihat sebagai salah satu komponen asosiatif yang dikenal oleh pemakna tanda. Misalnya pada kontrak BOT bidang pasar. Untuk mencapai kesejajaran hak dan kewajiban maka makna hak dan kewajiban harus diasosiasikan, apa yang sebutkan dalam teks kewajiban pihak A harus muncul pada teks hak pihak B begitu sebaliknya. Contohnya kerjasama BOT yang dibuat oleh Pemda Kota Malang dengan PT. CGA.

Di dalam klausul perjanjian menyebutkan bahwa Pemda kota Malang berkewajiban memberikan lahan Pasar Dinoyo Kota Malang keapda PT. CGA bilamana tempat penampungan sementara telah selesai dibangun. Serta dalam objek perjanjian tidak ada lagi pedagang yang masih berada di lahan objek perjanjian BOT Pasar Kota Malang, namun makna yang muncul dalam teks sebagai kewajiban pemerintah tersebut tidak disebutkan dalam hak PT. CGA. Oleh karena itu makna yang terdapat dalam hak dan kewajiban yang terdapat di perjanjian kerjasama ini bukan satu komponen perjanjian yang diasosiasikan sehingga pemahaman terhadap teks perjanjian kerjasama tersebut dikategorikan sebagai "non hak dan kewajiban". 
Kedua, sintagmatik, ini merupakan dimensi yang melihat suatu tanda dalam kaitan dengan tanda yang dalam ruang yang sama. Jadi , Hak dan kewajiban Kerjasama dengan skema pembiayaan BOT bidang pasar Dinoyo antara Pemda Kota Malang dan PT CGA dapat dimaknai bahwa perjanjian yang ada di dalamnya terdapat pembangunan, pengelolaan, penyerahan yang objeknya perjanjiannya adalah pasar dan pedagang sebagai pihak yang berimplikasi langsung terhadap perjanjian ini merupakan komponen dari paradigma. Kemudian dari komponen itu dari dimensi sintagmatik pada perjanjian diatas dapat dimaknai sebagai “Perjanjian kerjasama Pembangunan, pengelolaan, dan penyerahan bidang Pasar".

Namun realitas dari teks dari makna itu sebenarnya tidak demikian sebab perjanjian tersebut diberi nama perjanjian pembangunan dan pengelolaan, bukan makna BOT sebenarnya seperti disebutkan di atas. Begitu pula dengan objek perjanjian yang disebutkan dalam teks, pedagang dijadikan sebagai objek bukan sebagai subjek dari realitas sosial atau pihak ketiga yang terkena dampak atas pembangunan pasar tersebut.

Ketiga, analogi (Abdullah 2017e), dimensi yang melihat tanda seperti yang dilihat oleh (para) informan kita. Data yang dihadapkan kepada informan diberi makna sesuai analogi yang terbentuk pada diri informan. Dari penafsrian atas teks-teks dari makna yang muncul dalam hak dan kewajiban dalam kerjasama dengan skema pembiayaan BOT bidang pasar Dinoyo antara Pemda Kota Malang dan PT CGA. Makna dibalik kontrak tersebut memberikan pemahaman bahwa hak dan kewajiban dari teks perjanjian bukan merupakan komponen yang diasosiasikan. Dan relasi antara teks masih terpisah, tidak menjadi teks dalam ruang dan waktu yang sama.

Makna di atas memiliki kesamaan teks dengan perjanjian sewa menyewa bangunan ruko,toko, dsb. Teks pada perjanjian ini pun seringkali tidak satu komponen asosiatif sebab hak dan kewajiban terkadang tidak match. Begitu pula dengan relasi antara teks perjanjian, terkadang teks pada perjanjian yang dibuat tidak melihat dampak masyarakat, seperti halnya HO atau izin gangguan. Sehingga teks dalam hak dan kewajiban tidak dalam satu ruang dan waktu yang sama. 


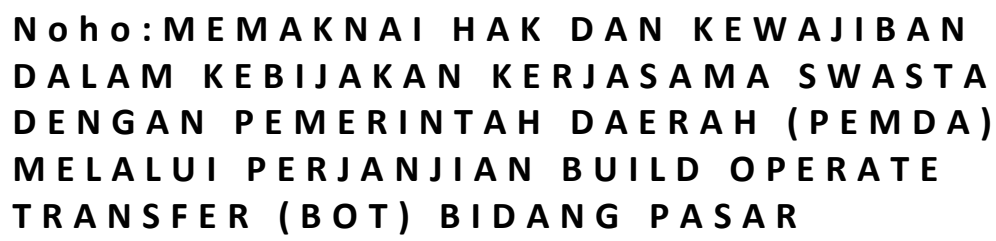

\section{KESIMPULAN}

Diantaranya tiga pihak utama yang seringkali muncul dalam kontrak BOT bidang pasar adalah pemilik lahan dan pengelola lahan. Dalam menjalankan fungsi skema BOT wajib mengatur hak dan kewajiban untuk memberikan batasan-batasan serta kewenangan para pihak dalam bertindak. Kontrak konstruksi BOT ini berkembang dan memunculkan berbagai jenis kontrak BOT, salah satunya BOT bidang pasar. Di dalam Kontrak BOT bidang Pasar hak dan kewajiban para pihak bermacam-macam, diantaranya ada pihak yang memberikan izin atas lahan beserta turunanya dan ada pihak yang membangun dan mengoperasionalisasikan pembangunan tersebut sekaligus menyerahkan bangunan itu bilamana masa konsesinya telah habis.

Dalam Memaknai kesejajaran pemahaman hak dan kewajiban atas kebijakan kerjasama pemerintah daerah dengan swasta melalui kontrak BOT bidang pasar penulis menggunakan teori the signifiying order dan analisa tiga dimensi yang dicetuskan oleh Danesi dan Perron. Teori the signifiying order mengganggap pemahaman dalam kontrak BOT bidang pasar harus merepresentasikan realitas baik itu sosial maupun hukum, kedua realitas ini harus ada agar menyeimbangi kedudukan para pihak. Sedangkan melalui analisa tiga dimensi, hak dan kewajiban kontrak BOT bidang pasar dipahami sebagai teks perjanjian yang bukan merupakan komponen yang diasosiasikan. Relasi antara teks masih terpisah, tidak menjadi teks dalam ruang dan waktu yang sama. Harusnya hak dan kewajiban kontrak dapat menjadi satu komponen yang diasosiasikan makna teks tersebut, dan relasi teks antara hak dan dan kewajiban dalam satu teks kontrak dengan teks yang lain seperti pedagang dapat berada dalam satu kedudukan hak dan kewajiban yang sama.

\section{REFERENSI}

Abbas, Moeh. Yafie. n.d. "Public Private Partnership Dalam Pembangunan Dan Pengelolaan Suncity Plaza Sidoarjo (Model Perjanjian Build Operate Transfer (BOT) Antara Pemerintah Kabupaten Sidoarjo Dengan PT. Indraco)." 1.

Abdullah, Ignas Kleden dan Taufik. 2017a. "Paradigma Ilmu Pengetahuan Dan Penelitian Ilmu-Ilmu Sosial Dan Humaniora Di Indonesia." 464-66. 
Abdullah, Ignas Kleden dan Taufik. 2017b. "Paradigma Ilmu Pengetahuan Dan Penelitian Ilmu-Ilmu Sosial Dan Humaniora Di Indonesia." 477.

Abdullah, Ignas Kleden dan Taufik. 2017c. "Paradigma Ilmu Pengetahuan Dan Penelitian Ilmu-Ilmu Sosial Dan Humaniora Di Indonesia." 464.

Abdullah, Ignas Kleden dan Taufik. 2017d. "Paradigma Ilmu Pengetahuan Dan Penelitian Ilmu-Ilmu Sosial Dan Humaniora Di Indonesia." 465.

Abdullah, Ignas Kleden dan Taufik. 2017e. "Paradigma Ilmu Pengetahuan Dan Penelitian Ilmu-Ilmu Sosial Dan Humaniora Di Indonesia." 466.

Adha, Lalu Hadi. 2011. "Kontrak Build Operate Transfer Sebagai Perjanjian Kebijakan Pemerintah Dengan Swasta.” Jurnal Dinamika Hukum 11(3):549.

Anon. 2011. "Dokumen Perjanjian Kerjasama Antara Pemerintah Kota Malang Dengan PT Citra Gading Asritama Tentang Pembangunan Dan Pengelolaan Kawasan Pasar Terpadu Dinoyo.”

Durbar, Singa. 2000. "National Planing Commision." 1.

Justisia, Vita. 2015. "Perjanjian Bangun Guna Serah (Build, Operate And Transfer) Antara Pemerintah Provinsi Sumatera Selatan Dengan Pihak Swasta." Jurnal Nurani 15(1):73-84.

Kusumohamidjojo, Budiono. 2015. "Perbandingan Hukum Kontrak (Comparative Cotract Law)." 10-11.

Lutfi, Mochtar. n.d. "Pemahaman Konseptual Dan Metodologis." Jurnal Hermeneutika 4.

Masitoh, Hidayatul. 2014a. "Public Private Partnership (PPP) Pengelolaan Aset Daerah: Studi Deskriptif Tentang Kemitraan Antara Perusahaan Daerah Pasar Surya (PDPS) Surabaya Dengan PT Arwinto Intan Wijaya (AIW) Dalam Pembangunan Dan Pengembangan Darmo Trade Centre(DTC) Surabaya." Jurnal Kebijakan Dan Manajemen Publik 2(1):1.

Masitoh, Hidayatul. 2014b. "Public Private Partnership (PPP) Pengelolaan Aset Daerah: Studi Deskriptif Tentang Kemitraan Antara Perusahaan Daerah Pasar Surya (PDPS) Surabaya Dengan PT Arwinto Intan Wijaya (AIW) Dalam Pembangunan Dan Pengembangan Darmo Trade Centre(DTC) Surabaya." Jurnal Kebijakan Dan Manajemen Publik 2(1):2.

Mulyati, Etty. 2016. “Asas Keseimbangan Pada Perjanjian Kredit Perbankan Dengan Nasabah Pelaku Usaha Kecil.” Jurnal Bina Mulia Hukum 1(1):39.

Prasetyo, Sudikno Mertokusumo dalam Hananto. 2017. "Pembaharuan Hukum Perjanjian Sportentertainment Berbasis Nilai Keadilan (Studi Kasus Pada Petinju Profesional Di Indonesia).” Jurnal Pembaharuan Hukum 4(1):67.

Santoso, Budi. 2008. Aspek Hukum Pembiayaan Proyek Infrastruktur Dengan Metode BOT (Build Operate Transfer). Yogyakarta: Genta Press.

Setlight, Mercy Maria Magdalena. 2011. "Karakteristik Perjanjian Bangun Guna Serah, Lex et Societatis." Jurnal Dinamika Hukum 1(4):146.

Smith, C. Walker and A. J. 1999. "The Build Operate Transfer Approach." Privatized Infrastructure 5.

Thohir, Mudjahirin. 2007a. "Memahami Kebudayaan Teori, Metodologi, Dan 


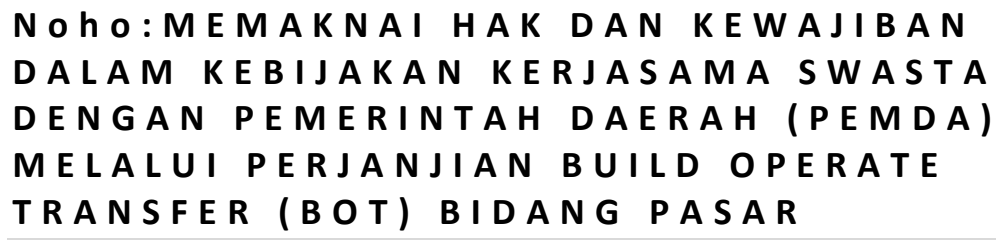

Aplikasi." 49.

Thohir, Mudjahirin. 2007b. "Memahami Kebudayaan Teori, Metodologi, Dan Aplikasi." 54.

Thohir, Mudjahirin. 2007c. "Memahami Kebudayaan Teori, Metodologi, Dan Aplikasi." 313.

Thohir, Mudjahirin. 2007d. "Memahami Kebudayaan Teori, Metodologi, Dan Aplikasi." 314.

Thohir, Mudjahirin. 2007e. "Memahami Kebudayaan Teori, Metodologi, Dan Aplikasi." 483.

Urbanus Ura Weruin, Dkk. 2016. “Hermeneutika Hukum:Prinsip Dan Kaidah Interpretasi Hukum.” Jurnal Konstitusi 13(1):103. 